\title{
MODEL MANAJEMEN KONFLIK BERBASIS KEARIFAN LOKAL: KONFLIK PERGURUAN PENCAK SILAT DI MADIUN - JAWA TIMUR
}

\author{
Estu Widiyowati ${ }^{1, a)}$ Rachmat Kriyantono ${ }^{2,}$ Bambang Dwi Prasetyo ${ }^{3}$ \\ ${ }^{1}$ Pascasarjana Ilmu Komunikasi Universitas Brawijaya, Malang \\ ${ }^{2}$ Pascasarjana Ilmu Komunikasi Universitas Brawijaya, Malang \\ ${ }^{3}$ Pascasarjana Ilmu Komunikasi Universitas Brawijaya, Malang \\ a)estuwidiyowati@gmail.com
}

DOl:https://doi.org/10.18196/jkm.101004

Info artikel

Sejarah artikel :

Diterima 7 Feb 2018

Revisi 20 Mar 2018

Disetujui 20 Mar 2018

\begin{abstract}
The purpose of this research is to analyze the meaning of the role of local wisdom value in conflict management process and to mapping of the conflict management model based on local wisdom of the Madiun community. This research uses qualitative descriptive approach with phenomenology method. Selection of informants were taken purposive sampling. The data were collected by observation and in - depth interviews technique. The result show that the value of Javanese culture as a local wisdom value Madiun community which by the traditional martial members interpreted as the main life guide, the conflict management process must also prioritize the local wisdom value that aims to realize lasting peace. Mapping of conflict management model is based on Javanese ethics, hamemayu hayuning bawono, and mangan ora mangan anggere kumpul. The mapping demonstrates that elitism is a main characteristic of the conflict management model in Madiun, especially in managing community conflict.
\end{abstract}

Keyword : Traditional Martial, Confllict Management, Javanese Culture, Asia Communication Perspective

\begin{abstract}
ABSTRAK
Penelitian ini bertujuan untuk menganalisis pemaknaan peran nilai kearifan lokal dalam proses manajemen konflik dan untuk memetakan model manajemen konflik yang sesuai dengan nilai kearifan lokal masyarakat Madiun. Penelitian ini menggunakan pendekatan kualitatif deskriptif dengan metode fenomenologi. Pemilihan informan dilakukan dengan menggunakan purposive sampling. Pengumpulan data dilakukan dengan menggunakan teknik observasi dan wawancara mendalam. Hasil penelitian menunjukkan bahwa nilai budaya Jawa sebagai nilai kearifan lokal masyarakat Madiun yang ole anggota perguruan dimaknai sebagai pedoman idup utama, maka proses manajemen konflik juga harus berpedoman pada nilai kearifan lokal yang bertujuan untuk mewujudkan perdamaian jangka panjang. Pemetaan model manajemen konflik dilakukan dengan berpedoman pada nilai etika Jawa, hamemayu hayuning bawono, dan mangan ora mangan anggere kumpul. Pemetaan model manajemen konflik berdasarkan pada nilai kearifan lokal dapat menunjukkan bahwa ketokohan merupakan karakteristik utama dari model manajemen konflik di Madiun, khususnya dalam mengelola konflik masyarakat.
\end{abstract}

Kata Kunci: Pencak Silat, Manajemen Konflik, Budaya Jawa, Perspektif Komunikasi Asia

\section{PENDAHULUAN}

Keanekaragaman suku, agama, ras, dan budaya, serta jumlah penduduk yang lebih dari 230 juta jiwa yang dimiliki oleh negara Indonesia, disatu sisi memberikan kontribusi yang positif dalam upaya menciptakan 
kesejahteraan masyarakat (Fahmi \& Akbar, 2015; Neumeyer, 2006; Schefold, 1998). Namun, disisi lain, keanekaragaman tersebut dengan disertai semakin cepatnya dinamika sosial, menempatkan Indonesia sebagai salah satu negara yang rawan konflik, terutama konflik yang bersifat horisontal (Fahmi \& Akbar, 2015; Neumeyer, 2006; Bräuchler, 2009). Adapun sumber konflik yang melatarbelakangi terjadinya konflik sosial di Indonesia diantaranya permasalahan yang berkaitan dengan ideologi, politik, ekonomi, sosial, budaya, isu SARA, dan sengketa lahan (Data Konflik Sosial, Kesbangpol, 2015).Berkaitan dengan eskalasi konflik di Indonesia, Madiun yang berada di Provinsi Jawa Timur merupakan salah satu wilayah yang sangat rawan konflik sosial (Data Konflik Sosial, Kesbangpol, 2015). Salah satu bentuk konflik sosial yang terjadi di Madiun adalah konflik antara dua perguruan pencak silat, yaitu Persaudaraan Setia Hati Terate dan Persaudaraan Setia Hati Winongo Tunas Muda (Firmansyah, 2016; Gustiana, 2013; Listiana, 2014; Maksum, 2009; Sasmito, 2016; Yulianie, 2015). Kedua perguruan tersebut merupakan perguruan pencak silat tertua dan terbesar di Madiun, yang juga memiliki sejarah konflik yang panjang dan periodik (Gustiana, 2013; Listiana, 2014). Berdasarkan temuan data penelitian dengan didukung hasil dari penelitian terdahulu yang dilakukan diantaranya oleh Firmansyah (2016), Gustiana (2013), Listiana (2014), Maksum (2009), dan Yuliane (2015), konflik antara kedua perguruan dilatarbelakangi oleh sikap dari anggota kedua perguruan yang saling merasa sebagai pembawa asli ajaran Setia Hati, fanatisme yang tinggi dari anggota kedua perguruan, dan kurangnya pemahaman dari anggota perguruan mengenai ajaran Setia Hati yang berdampak pada munculnya sikap merasa yang paling benar.

Definisi konflik, apabila dilihat melalui sudut pandang masyarakat Jawa, yaitu sebagai suatu kondisi yang mengganggu keselarasan atau harmoni sosial (Suseno, 2003). Keselarasan atau harmoni sosial merupakan salah satu aspek penting dalam mempertahankan hubungan (Suseno, 1985, dikutip di Leung \& Tjosvold, 1999) dengan berorientasi pada pandangan kosmologi, yaitu pandangan mengenai dua kosmos, yaitu makrokosmos (jagad gedhe) dan mikrokosmos (jagad cilik) (Mulder, 1983; Suseno, 2003; Wahyono, 2003). Pandangan kosmologi tersebut memberikan pengaruh pada setiap perilaku masyarakat Jawa, yaitu untuk selalu berpedoman pada keseimbangan kedua kosmos tersebut agar memperoleh tentrem dan slamet (Mulder, 1983; Suseno, 2003; Wahyono, 2003). Konflik yang terjadi dapat berupa perselisihan, adaya ketegangan, dan kesulitan - kesulitan lain pada pihak - pihak yang berkonflik serta seringkali diekspresikan melalui cara - cara berupa kekerasan, perdebatan, dan kemarahan (Tjosvold, dkk., 2003).

Potensi konflik muncul ketika diantara anggota masyarakat cenderung mengutamakan kepentingan individu ataupun kelompok sehingga terjadi persaingan yang dapat memicu terjadinya konflik (Thomas \& Schmidt, 1976, dikutip di Oetzel \& Ting - Toomey, 2006; Wilmot \& Hocker, 2001). Potensi konflik pada dasarnya juga mengikuti pola - pola yang berlaku pada munculnya konflik antarindividu (Suparlan, 2006). Konflik antarindividu dapat memicu terbentuknya konflik yang lebih luas ketika konflik yang terjadi juga melibatkan anggota keluarga dan kerabat, serta komunitas atau masyarakat dari kedua pihak yang berkonflik (Suparlan, 2006). Artinya konflik yang terjadi bukan merupakan konflik antara orang per orang, melainkan antara orang per orang yang mewakili suatu golongan atau kelompok (Suparlan, 2006).

Secara khusus, Suparlan (2006) menegaskan bahwa konflik yang merupakan perluasan dari konflik individual, terwujud dalam bentuk konflik fisik atau perang antar dua kelompok atau lebih yang biasanya selalu terjadi dalam keadaan berulang. Kondisi tersebut juga diistilahkan sebagai conflict trap, yakni ketika suatu kelompok, wilayah, atau bahkan negara yang pernah mengalami konflik di masa lalu maka secara signifikan beresiko mengalami episode konflik skala besar di kemudian hari (Collier, Elliot, Hegre, Hoeffler, Querol, \& Sambanis, 2003; Walter, 2010). Sasaran dalam konflik ialah keseluruhan golongan atau kelompok, sehingga penghancuran terhadap diri atau harta milik orang per orang dari pihak lawan, diposisikan sama dengan penghancuran kelompok pihak lawan (Suparlan, 2006). Mengacu pada penjelasan tersebut, konflik antara perguruan pencak silat Persaudaraan Setia Hati Terate dan Persaudaraan Setia Hati Winongo Tunas Muda tergolong konflik yang terjadi secara berulang yang terjadi mulai tahun 1980 - an.

Proses manajemen konflik, berupa dialog dan mediasi, antara perguruan Persaudaraan Setia Hati Terate dan Persaudaraan Setia Hati Winongo Tunas Muda sudah dilakukan oleh pengurus dua perguruan tersebut, yang juga melibatkan peran tokoh masyarakat, utamanya dari pemerintah dan aparat keamanan (TNI/ POLRI). Proses manajemen konflik yang telah dilakukan menghasilkan dua kesepakatan, yaitu Ikrar Damai dan pembentukan Paguyuban Madiun Kampung Pesilat. Ditetapkannya Ikrar Damai antara dua perguruan dan dibentuknya Paguyuban Madiun Kampung Pesilat, dapat dikatakan sedikit membawa perubahan yang lebih baik, secara khusus pada saat Bulan 
Suro, ketika dua perguruan melakukan kegiatan tahunan. Pada Bulan Suro ini seringkali dua perguruan terlibat konflik dengan tingkat eskalasi konflik yang tinggi.Perubahan tersebut ditunjukkan pada tahun 2017, didasarkan pada data dari Kepolisian Resort Madiun, pada kegiatan Bulan Suro dari dua perguruan tidak terjadi konflik.

Namun perubahan tersebut bukan berarti bahwa konflik sudah berhenti, potensi konflik tetap muncul diluar kegiatan Bulan Suro, yaitu dalam keseharian anggota perguruan.Potensi konflik sangat mudah muncul dalam keseharian anggota perguruan dengan dilatarbelakangi oleh macam - macam faktor, diantaranya pendirian tugu perguruan, pengrusakan tugu perguruan, dan pemasangan spanduk perguruan.Faktor - faktor tersebut sangat berdampak pada munculnya prasangka - prasangka negatif antara anggota dua perguruan, yang pada akhirnya juga berdampak pada terjadinya konflik. Berdasarkan pada kondisi tersebut dan berkaitan dengan proses manajemen konflik, disatu sisi, peran dari pemerintah dan aparat keamanan - disebut pendekatan top down atau struktural, pada dasarnya sangat diperlukan untuk menjaga dan menciptakan perdamaian di suatu wilayah. Tetapi, disisi lain, proses manajemen konflik dengan menggunakan pendekatan top down atau struktural belum bisa menjamin terwujudnya perdamaian jangka panjang (Mufid, 2010; Panday \& Jamil, 2009). Proses manajemen konflik dengan menggunakan pendekatan top down atau stuktural hanya berorientasi pada kebijakan dari pemerintah maupun dari aparat keamanan (Azra, 1999; Mufid, 2010) atau cenderung bersifat formal (hitam di atas putih) (Suharno \& Samsuri, 2013) dan seringkali menggunakan mekanisme kekuasaan serta cenderung mengabaikan pola - pola kultural (Azra, 1999; Mufid, 2010). Sulaeman (2010) juga menjelaskan bahwa konflik seringkali dikelola dengan menggunakan cara yang represif dan kurang memperhatikan potensi lokal (Sulaeman, 2010).

Menanggapi penjelasan tersebut, Koentjaraningrat (1993) menjelaskan bahwa budaya, sebagai salah satu keberagaman di Indonesia, memiliki andil besar dalam upaya penyelesaian konflik sosial yang terjadi di masyarakat. Nilai - nilai sosial budaya memberikan pengaruh yang kuat pada proses manajemen konflik (Haar \& Krahé, 1999; Syukur \& Bagshaw, 2013), karena nilai budaya memiliki keunggulan yaitu sebagai seperangkat keyakinan dan perilaku dalam suatu masyarakat (Hindaryati, 2016). Kearifan lokal merupakan salah satu cara yang dianggap efektif dan efisien dalam mengelola konflik sosial (Astri, 2011; Bräuchler, 2009; Kusumasari \& Alam, 2012; Rasjidi \& Wyasa, 1993; Suprapto, 2013), karena dapat mendorong pihak yang berkonflik melakukan dialog dengan memanfaatkan kedekatan emosi dan budaya (Bräuchler, 2009), sehingga terwujud perdamaian dan kerukunan di masyarakat (Astri, 2011). Disamping itu, peranan dari kearifan lokal dalam pengelolaan konflik juga diatur secara yuridis di dalam Peraturan Pemerintah Republik Indonesia Pasal 3 Nomor 2 Tahun 2015 tentang Peraturan Undang - Undang Nomor 7 Tahun 2012 tentang Penanganan Konflik Sosial.

Nilai kearifan lokal yang berperan dalam mengelola konflik sosial di masyarakat, merupakan suatu aspek yang penting dalam memunculkan konsep komunikasi dengan perspektif non - Western (Asian Perspective).Dissanayake (2003) menegaskan bahwa kajian komunikasi Asia dapat dieksplorasi salah satunya melalui tradisi klasik dan praktik budaya untuk memahami komunikasi dari sudut pandang suatu wilayah budaya tertentu.

Penelitian komunikasi dengan menggunakan kajian komunikasi Asia sangat dibutuhkan, karena selama ini perkembangan studi komunikasi cenderung didominasi oleh sudut pandang Barat (Dissanayake, 2003). Hal tersebut terjadi karena adanya keterbatasan secara akademik, yaitu minimnya referensi komunikasi perspektif Asia, sehingga referensi yang digunakan oleh para ilmuwan komunikasi, seperti buku, jurnal, dan makalah penelitian, sebagian besar merupakan referensi yang diterbitkan di bawah dominasi ilmiah Barat (Dissanayake, 2003).

Berdasarkan pada urgensi tersebut di atas, maka perumusan masalah penelitian ini adalah, (1) Bagaimana anggota Persaudaraan Setia Hati Terate dan Persaudaraan Setia Hati Winongo Tunas Muda memaknai peran nilai - nilai kearifan lokal dalam proses manajemen konflik?; (2) Bagaimana identifikasi dan pemetaan model manajemen konflik sesuai dengan kearifan lokal masyarakat Jawa, khususnya Madiun sebagai wilayah kebudayaan Jawa Mataraman?.

\section{Tinjauan pustaka}

Aspek Sosiokultural Masyarakat Jawa Mataraman

Masyarakat Jawa di Jawa Timur memeiliki karakter budaya yang berbeda - beda sesuai dengan wilayah kebudayaannya (Sutarto \& Sudikan, 2004). Sutarto dan Sudikan (2004) mengelompokkan Jawa Timur berdasarkan pada wilayah kebudayaan, yaitu Jawa Mataraman, Jawa Panaragan, Arek, Samin, Tengger, Osing, Pandalungan, dan Madura Pulau. 
Penelitian ini fokus pada masyarakat Jawa Mataraman di Madiun.Wilayah kebudayaan Mataraman merupakan wilayah kebudayaan yang dipengaruhi kuat oleh budaya Kerajaan Mataram Kuno di Pulau Jawa (Sholihatin, 2013; Sutarto \& Sudikan, 2004), yang memiliki karakteristik umum, yaitu berakar pada budaya agraris, solidaritas desa yang kuat, dan gotong royong relatif kental (Sutarto \& Sudikan, 2004).

Sebagian besar masyarakat Jawa Mataraman, merupakan penganut agama Islam, namun dalam praktiknya, terdapat dua pengelompokkan, yakni kaum santri dan kaum abangan (Koentjaraningrat, 1994; Mulder, 1983). Masyarakat yang termasuk kaum abangan merupakan masyarakat muslim, namun tidak menjalankan ajaran Islam secara keseluruhan karena adanya aliran lain yang juga turut menjadi pedoman, yaitu kejawen (Geertz, 2014; Kontjaraningrat, 1994; Mulder, 1983).

Tradisi kejawen merupakan produk sinkritisme animisme - dinamisme, Hindu - Budha, dan Islam (Mulder, 1983; Simuh, 1997). Orang yang menganut kejawen, cenderung sangat religius dalam kesadaran mereka untuk berpartisipasi dalam kesatuan eksistensi dan ketergantungan pada prinsip kosmis yang mencakup segala yang mengatur kehidupan mereka (Mulder, 1983; Suseno, 2003; Wahyono, 2003) yang dalam hal ini juga mencakup cara pandang masyarakat Jawa Mataraman dalam mengelola konflik dan menciptakan kondisi baru yang lebih baik.

Strategi Manajemen Konflik

Indonesia adalah negara multikultural yang terdiri lebih dari 300 suku (Syukur \& Bagshaw, 2013). Masing - masing suku tersebut memiliki budaya dan cara yang berbeda - beda untuk menyelesaikan konflik. Keragaman budaya tersebut menjadikan Indonesia memiliki tiga sumber hukum yang saling mempengaruhi, yakni hukum Islam (syariah), hukum adat, dan hukum negara (Mills, 2006, dikutip di Syukur \& Bagshaw, 2013). Berbagai tradisi mempengaruhi masyarakat dalam proses pengelolaan konflik (Syukur \& Bagshaw, 2013).

Masyarakat Jawa Mataraman mengutamakan pelestarian hubungan jangka panjang dan harmoni dalam proses mengelola konflik (Benton \& Setiadi, 1998, dikutip di Syukur \& Bagshaw, 2013). Proses pengelolaan konflik diawali dengan proses pendefinisian konflik untuk mengetahui penyebab dari terjadinya konflik dan bentuk konflik yang terjadi. Kedua, perencanaan kegiatan, berupa pemilihan bentuk komunikasi yang akan digunakan - komunikasi formal atau komunikasi informal, dan siapa saja yang dilibatkan dalam proses komunikasi tersebut. Ketiga, yaitu tindakan, dan keempat, yaitu evaluasi.

Keseluruhan dari proses pengelolaan konflik tersebut berpedoman pada tiga dasar nilai, yaitu etika Jawa, nilai hamemayu hayuning bawono, dan nilai mangan ora mangan anggere kumpul. Latarbelakang tiga nilai tersebut menjadi pedoman utama dalam proses pengelolaan konflik masyarakat Jawa Mataraman karena pertama, ketiga nilai tersebut menjadi nilai yang paling inti atau esensial dalam kehidupan sosial dan dalam kehidupan masyarakat Jawa Mataraman. Kedua, ketiga nilai tersebut juga menjadi ajaran inti dalam dua perguruan pencak silat yang terlibat konflik, yaitu perguruan Persaudaraan Setia Hati Terate dan Persaudaraan Setia Hati Winongo Tunas Muda.

\section{METODE PENELITIAN}

Penelitian ini menggunakan paradigma Non - Western yang merupakan paradigma penelitian sosial yang berangkat dari nilai-nilai filosofis masyarakat lokal menuju penemuan sebuah struktur nyata dari pandangan nilai kearifan lokal tersebut di dunia (Neuman, 2013; Zuliansyah, 2017).Penemuan tersebut bertujuan membantu mengubah keadaan masyarakat dan membangun dunia yang lebih baik bagi mereka sendiri (Neuman, 2013).Paradigma non - Western dalam penelitian ini menjadi landasan dasar peneliti melakukan analisis fenomena konflik yang terjadi antara perguruan pencak silat Setia Hati Terate dan Setia Hati Winongo Tunas Muda.

Jenis penelitian menggunakan penelitian kualitatif deskriptif dengan fenomenologi sebagai metodologi penelitian.Pemilihan informan penelitian menggunakan teknik purposive sampling, yaitu teknik pemilihan informan berdasarkan pada beberapa pertimbangan (Neuman, 2013; Sugiyono, 2007). Hal - hal yang digunakan sebagai pertimbangan dalam pemilihan informan, diantaranya informan memahami konflik, merasakan situasi konflik, dan terlibat dalam proses manajemen konflik. Informan dalam penelitian ini adalah pengurus perguruan pencak silat Persaudaraan Setia Hati Terate dan Persaudaraan Setia Hati Winongo Tunas Muda dan anggota perguruan yang sudah disahkan dalam kurun waktu lima sampai 15 tahun. Berkaitan dengan batas informan penelitian, peneliti menggunakan konsep redundancy atau saturasi, yaitu penentuan batas informan berdasarkan kebaruan 
data (Hesse - Bibber \& Leavy, dikutip di Kriyantono, 2007; Nasution, 1988, dikutip di Sugiyono, 2007).

Metode pengumpulan data dilakukan dengan menggunakan teknik observasi partisipan dan wawancara mendalam. Data yang terkumpul dianalisis menggunakan model Miles dan Huberman yang terdiri dari proses reduksi data, penyajian data, dan penarikan kesimpulan atau verifikasi (Miles \& Huberman, 1994, dikutip di Sugiyono, 2005).

Tabel 1.Profil Informan

\begin{tabular}{|c|c|}
\hline Informan & Profil Informan \\
\hline $\mathrm{MK}$ & $\begin{array}{l}\text { Merupakan pengurus inti di perguruan pencak silat Persaudaraan Setia Hati Terate } \\
\text { dan Paguyuban Madiun Kampung Pesilat. MK mulai berlatih di perguruan pencak silat } \\
\text { Persaudaraan Setia Hati Terate pada tahun } 1968 \text { dan disahkan sebagai anggota pada } \\
\text { tahun 1972. Peneliti memilih MK sebagai informan penelitian dengan asumsi bahwa } \\
\text { sebagai pengurus inti, tentunya MK sangat paham mengenai sejarah dari perguruan, } \\
\text { sejarah dan peta konflik yang terjadi antara perguruan Persaudaraan Setia Hati Terate } \\
\text { dan Persaudaraan Setia Hati Winongo Tunas Muda, serta proses manajemen konflik } \\
\text { yang telah dilakukan antar pengurus dua perguruan tersebut. }\end{array}$ \\
\hline AY & $\begin{array}{l}\text { Merupakan pengurus inti di perguruan pencak silat Persaudaraan Setia Hati Winongo } \\
\text { Tunas Muda. AY mulai aktif di perguruan pencak silat Persaudaraan Setia Hati } \\
\text { Winongo Tunas Muda pada tahun 1978. Peneliti memilih AY sebagai informan } \\
\text { penelitian didasarkan pada asumsi bahwa sebagai pengurus inti, tentunya AY sangat } \\
\text { paham mengenai sejarah perguruan, sejarah dan peta konflik yang terjadi antara } \\
\text { Persaudaraan Setia Hati Terate dan Persaudaraan Setia Hati Winongo Tunas Muda, serta } \\
\text { proses manajemen konflik yang telah dilakukan oleh pengurus dua perguruan tersebut. }\end{array}$ \\
\hline $\mathrm{AP}$ & $\begin{array}{l}\text { Merupakan anggota dari perguruan pencak silat Persaudaraan Setia Hati Winongo } \\
\text { Tunas Muda. AP merupakan seseorang yang ditokohkan oleh anggota - anggota tingkat } \\
\text { bawah dari Persaudaraan Setia Hati Winongo Tunas Muda. Peneliti memilih AP sebagai } \\
\text { informan penelitian dengan asumsi bahwa sebagai seseorang yang ditokohkan, tentunya } \\
\text { AP memahami sumber konflik yang terjadi dari sisi anggota di tingkat bawah. Selain itu, } \\
\text { AP juga tentunya mengetahui bentuk - bentuk implementasi segala kebijakan dari hasil } \\
\text { proses manajemen konflik yang dilakukan oleh pengurus pusat kepada anggota di } \\
\text { tingkat bawah. }\end{array}$ \\
\hline SG & $\begin{array}{l}\text { Merupakan anggota dari perguruan pencak silat Persaudaraan Setia Hati Terate. SG } \\
\text { mulai mengikuti latihan pencak silat pada kisaran tahun } 2006-2007 \text { dan disahkan } \\
\text { sebagai anggota pada tahun 2008. AP merupakan seseorang yang ditokohkan oleh } \\
\text { anggota dari Persaudaraan Setia Hati Terate dan anggota dari Persaudaraan Setia Hati } \\
\text { Winongo Tunas Muda. Peneliti memilih SG sebagai informan penelitian berdasarkan } \\
\text { pada asumsi bahwa SG memahami kondisi di anggota tingkat bawah, terutama berkaitan } \\
\text { dengan konflik yang terjadi, selain itu SG juga tentunya mengetahui proses manajemen } \\
\text { konflik yang berlangsung diantara pengurus perguruan di tingkat pusat dan } \\
\text { implementasinya di tingkat bawah. }\end{array}$ \\
\hline $\mathrm{SO}$ & $\begin{array}{l}\text { Merupakan anggota dari perguruan pencak silat Persaudaraan Setia Hati Terate. SO } \\
\text { mulai ikut latihan pencak silat pada pertengahan tahun } 2007 \text { dan disahkan menjadi } \\
\text { anggota pada tahun 2008. Selama aktif di Persaudaraan Setia Hati Terate, SO pernah } \\
\text { berada atau merasakan secara langsung pada saat konflik terjadi. Peneliti memilih SO } \\
\text { sebagai informan penelitian berdasarkan pada asumsi bahwa SO memahami bentuk - } \\
\text { bentuk konflik yang terjadi dan pemicu terjadinya konflik di antara anggota - anggota } \\
\text { perguruan di tingkat bawah. }\end{array}$ \\
\hline $\mathrm{BG}$ & $\begin{array}{l}\text { Merupakan pelatih di perguruan pencak silat Persaudaraan Setia Hati Terate. BG } \\
\text { mulai mengikuti latihan pencak silat di Persaudaraan Setia Hati Terate pada tahun } 1984 \\
\text { dan disahkan menjadi anggota pada tahun 1986. Peneliti memilih BG sebagai informan } \\
\text { penelitian dengan asumsi bahwa sebagai pelatih, tentunya BG mengetahui karakter dari } \\
\text { anggota perguruan, mengetahui sumber penyebab konflik yang terjadi di anggota tingkat } \\
\text { bawah, juga mengetahui bentuk - bentuk kegiatan manajemen konflik yang berlangsung }\end{array}$ \\
\hline
\end{tabular}


di tingkat pusat maupun di tingkat bawah.

\begin{tabular}{|c|c|}
\hline $\mathrm{AD}$ & $\begin{array}{l}\text { Merupakan pelatih di perguruan pencak silat Persaudaraan Setia Hati Terate. Mulai } \\
\text { ikut latihan pencak silat pada tahun } 1993 \text { dan disahkan sebagai anggota pada tahun } \\
\text { 1996. Peneliti memilih AD sebagai informan penelitian dengan asumsi bahwa sebagai } \\
\text { pelatih, tentunya AD mengetahui karakter dari anggota perguruan, mengetahui sumber } \\
\text { penyebab konflik yang terjadi di anggota tingkat bawah, juga mengetahui bentuk - } \\
\text { bentuk kegiatan manajemen konflik yang berlangsung di tingkat pusat maupun di } \\
\text { tingkat bawah. }\end{array}$ \\
\hline $\mathrm{DB}$ & $\begin{array}{l}\text { Merupakan pelatih di perguruan pencak silat Persaudaraan Setia Hati Winongo } \\
\text { Tunas Muda. DB mulai aktif di Persaudaraan Setia Hati Winongo Tunas Muda pada } \\
\text { tahun } 2008 \text { hingga sekarang. Peneliti memilih DB sebagai informan penelitian dengan } \\
\text { asumsi bahwa sebagai pelatih, tentunya DB mengetahui karakter dari anggota } \\
\text { perguruan, mengetahui sumber penyebab konflik yang terjadi di anggota tingkat bawah, } \\
\text { juga mengetahui bentuk - bentuk kegiatan manajemen konflik yang berlangsung di } \\
\text { tingkat pusat maupun di tingkat bawah. }\end{array}$ \\
\hline MR & $\begin{array}{l}\text { Merupakan anggota di perguruan pencak silat Persaudaraan Setia Hati Winongo } \\
\text { Tunas Muda. MR mulai aktif di Persaudaraan Setia Hati Winongo Tunas Muda pada } \\
\text { tahun 2012. Selama aktif di Persaudaraan Setia Hati Winongo Tunas Muda, MR pernah } \\
\text { berada secara langsung ketika konflik terjadi, selain itu MR juga pernah terlibat dalam } \\
\text { kegiatan di Paguyuban Madiun Kampung Pesilat. Peneliti memilih MR sebagai } \\
\text { informan penelitian didasarkan pada asumsi bahwa MR memahami bentuk - bentuk } \\
\text { konflik yang terjadi dan pemicu terjadinya konflik di antara anggota - anggota } \\
\text { perguruan di tingkat bawah serta berbagai kegiatan Paguyuban Maidun Kampung } \\
\text { Pesilat. }\end{array}$ \\
\hline JP & $\begin{array}{l}\text { Merupakan pelatih dari perguruan pencak silat Persaudaraan Setia Hati Winongo } \\
\text { Tunas Muda. JP mulai aktif di Persaudaraan Setia Hati Winongo Tunas Muda pada } \\
\text { tahun 2012. MR pernah berada secara langsung ketika konflik terjadi. Peneliti memilih } \\
\text { JP sebagai informan penelitian dengan asumsi bahwa sebagai pelatih tentunya JP } \\
\text { mengetahui karakter dari anggota perguruan, mengetahui sumber penyebab konflik yang } \\
\text { terjadi di anggota tingkat bawah, juga mengetahui bentuk - bentuk kegiatan manajemen } \\
\text { konflik yang berlangsung di tingkat pusat maupun di tingkat bawah. Selain itu sebagai } \\
\text { informan yang mengetahui secara langsung saat konflik terjadi, tentunya JP juga } \\
\text { memahami bentuk - bentuk konflik yang terjadi dan pemicu terjadinya konflik di antara } \\
\text { anggota - anggota perguruan di tingkat. }\end{array}$ \\
\hline $\mathrm{SN}$ & $\begin{array}{l}\text { Merupakan pelatih di perguruan pencak silat Persaudaraan Setia Hati Winongo } \\
\text { Tunas Muda. Selama aktif di Persaudaraan Setia Hati Winongo Tunas Muda, SN } \\
\text { seringkali mendampingi anggota - anggota perguruan dalam berbagai kegiatan, juga } \\
\text { aktif dalam kepengurusan di tingkat ranting. Peneliti memilih SN sebagai informan } \\
\text { penelitian dengan asumsi bahwa dilihat dari keaktifan SN, sebagai pelatih maupun } \\
\text { sebagai pengurus ranting, tentunya SN mengetahui karakter dari anggota perguruan, } \\
\text { mengetahui sumber penyebab konflik yang terjadi di anggota tingkat bawah, juga } \\
\text { mengetahui bentuk - bentuk kegiatan manajemen konflik yang berlangsung di tingkat } \\
\text { pusat maupun di tingkat bawah. }\end{array}$ \\
\hline
\end{tabular}

\section{PEMBAHASAN}

\section{Pemaknaan Peran Nilai Kearifan Lokal Jawa Mataraman dalam Proses Manajemen Konflik}

Pengelompokkan wilayah di Jawa Timur yang didasarkan pada wilayah kebudayaannya, menempatkan Madiun dalam wilayah kebudayaan Jawa Mataraman (Sutarto \& Sudikan, 2004). Hal tersebut berkaitan dengan penguasaan wilayah Madiun oleh Kerajaan Mataram dalam waktu yang 
lama, sehingga berdampak pada adanya kesamaan antara sistem nilai budaya masyarakat Madiun dengan sistem nilai budaya Kerajaan Mataram (Pemerintah Kabupaten Madiun, 2005). Karakteristik utama dari masyarakat Madiun sebagai bagian dari budaya Jawa Mataraman adalah pertama, dalam kehidupan sosial, masyarakat Jawa Mataraman memiliki solidaritas yang kuat dan gotong - royong yang relatif kental (Sutarto \& Sudikan, 2004). Kedua, berkaitan dengan sistem religi, masyarakat Jawa Mataraman sangat mengutamakan terwujud dan terjaganya keseimbangan hubungan antara sesama manusia, dengan alam semesta, dan dengan Sang Pencipta (Sutarto \& Sudikan, 2004). Konflik yang terjadi di Madiun merupakan konflik antara perguruan pencak silat Persaudaraan Setia Hati Terate dan Persaudaraan Setia Hati Winongo Tunas Muda yang berlangsung secara periodik dan dalam kurun waktu yang sangat lama, dimulai dari tahun 1980 - an sampai sekarang.

Mengacu pada Koentjaraningrat (1993) yang menyatakan bahwa budaya memiliki andil besar dalam upaya penyelesaian konflik di masyarakat, pentingnya peranan budaya Jawa dalam proses manajemen konflik dalam fenomena konflik antara perguruan pencak silat Persaudaraan Setia Hati Terate dan Persaudaraan Setia Hati Winongo Tunas Muda dipengaruhi oleh pertama, pada dasarnya ajaran - ajaran dari kedua perguruan pencak silat sangat dipengaruhi oleh nilai - nilai budaya Jawa, utamanya dalam hal olah batin. Ajaran - ajaran tersebut akan dibawa sebagai pedoman mereka dalam kehidupan sehari - hari anggota kedua perguruan, baik sebagai anggota perguruan maupun sebagai anggota masyarakat. Kedua, dipengaruhi oleh pandangan anggota perguruan sebagai masyarakat Madiun yang menempatkan budaya Jawa sebagai pedoman hidup yang memiliki nilai - nilai dan ajaran - ajaran yang adiluhung, sehingga sebagai orang Jawa, nilai - dan ajaran tersebut harus dijaga dan diterapkan dalam kehidupan, ketika mereka meninggalkan nilai dan ajaran tersebut maka akan dianggap sebagai orang yang lupa dengan identitas budayanya atau dianggap tidak jawani. Keharmonisan sebagai keutamaan dalam kehidupan anggota perguruan sebagai bagian dari masyarakat Madiun sekaligus juga sebagai penganut budaya Jawa digambarkan melalui kondisi yang tentram dan selamat.Hal ini berkaitan dengan keseimbangan atau keselarasan antara jagad gedhe atau makrokosmos yaitu hubungan manusia dengan Tuhan dan alam semesta, dan jagad cilik atau mikrokosmos yaitu hubungan antara sesama manusia (Mulder, 1983; Suseno, 2003; Wahyono, 2003).Keharmonisan dalam kehidupan sosial masyarakat dapat terwujud apabila anggota perguruan sebagai bagian dari kehidupan masyarakat dapat menciptakan dan memelihara kerukukan dengan sesama anggota masyarakat.Dasar untuk mewujudkan kerukunan tersebut ialah dengan menumbuhkan kesadaran dalam diri anggota perguruan untuk selalu menjalin dan menjaga hubungan yang baik dengan anggota perguruan lainnya serta bersikap saling menghormati, karena setiap anggota perguruan memiliki sifat kebergantungan terhadap anggota perguruan lainnya dalam kehidupan sosialnya.

Nilai kearifan lokal sebagai suatu unsur yang penting dalam proses manajemen konflik yang dilakukan oleh kedua perguruan pencak silat karena selaras dengan pandangan filosofis dan kondisi sosial masyarakat Madiun. Hal tersebut juga dipertegas oleh Astri (2011) bahwa nilai kearifan lokal sebagai wujud keunggulan budaya yang mengandung nilai - nilai yang berlaku di masyarakat dan diyakini kebenarannya sebagai etika hidup. Berlatarbelakang dari konflik antara kedua perguruan yang terjadi dalam kurun waktu yang sangat lama dan periodik, maka proses manajemen konflik seharusnya tidak hanya bergantung pada hukum negara saja, artinya proses manajemen konflik antara kedua perguruan pencak silat juga harus memperhatikan aspek budaya. Masyarakat Madiun juga memiliki nilai kearifan lokal yang bersumber pada budaya lokal masyarakat, sehingga dalam proses penyelesaian konflik tidak bisa hanya mengandalkan hukum negara saja tanpa didorong dengan penguatan nilai - nilai kearifan lokal dalam kehidupan masyarakat. Peran nilai kearifan lokal dalam proses manajemen konflik antara kedua perguruan dinilai sebagai suatu strategi yang tepat untuk mewujudkan perdamaian jangka panjang antara kedua perguruan.

\section{Pemetaan Model Manajemen Konflik berdasarkan Nilai Kearifan Lokal Masyarakat Jawa Mataraman}

Berdasarkan pada karakteristik masyarakat Madiun, budaya Jawa dalam kehidupan sebagian besar masyarakat Madiun masih sangat kuat.Kuatnya budaya Jawa dalam kehidupan masyarakat Madiun berpengaruh terhadap pranata sosial masyarakat yang mengutamakan keharmonisan dalam kehidupan untuk mewujudkan kesejahteraan lahir dan batin, sehingga konflik yang terjadi dianggap sebagai aib dan sangat menganggu kehidupan sosial masyarakat Madiun.Berkaitan dengan proses manajemen konflik yang telah dilakukan oleh pengurus perguruan Persaudaraan Setia Hati Terate dan 
Persaudaraan Setia Hati Winongo Tunas Muda, pada dasarnya sudah sesuai dengan karakteristik dari budaya masyarakat Madiun. Dialog dan mediasi sebagai proses manajemen konflik merupakan pengejawentahan dari nilai gotong - royong (Littlejohn \& Domenici, 2001; Logdson, 1978, dikutip di Irawanto, Ramsey, \& Ryan, 2011; Suseno, 2003) dan bentuk komunikasi yang menghormati hubungan diatas perspektif, posisi, dan kepentingan individu (Littlejohn \& Domenici, 2001), yang menjadi inti dari nilai etika Jawa, hamemayu hayuning bawono, dan mangan ora mangan anggere kumpul.

Namun, dalam berlangsungnya proses dialog dan mediasi, terdapat beberapa aspek dari tiga dasar nilai budaya Jawa tersebut yang dirasa belum terpenuhi. Hal tersebut dapat menjadi penghambat dalam proses manajemen konflik. Beberapa aspek yang belum terpenuhi tersebut diantaranya, pertama, berkaitan dengan nilai etika Jawa. Terdapat dua kaidah dasar dalam etika Jawa, yaitu prinsip rukun dan prinsip hormat. Prinsip rukun dalam proses manajemen konflik berupaya untuk mengatur proses pengambilan keputusan (Suseno, 2003), yang mengacu pada aspek harmonious social appearances (Geertz, 1961, dikutip di Suseno, 2003; Suseno, 2003; Suseno, 1983; Willner, 1970, dikutip di Suseno, 2003) dan aspek egalitarian (Cooley, 1992, dikutip di Hawkins, 1996; Jay, 1969, dikutip di Hawkins, 1996). Harmonious social appearances merupakan upaya menjaga keselarasan dalam hubungan sosial (Geertz, 1961, dikutip di Suseno, 2003; Suseno, 2003; Suseno, 1983; Willner, 1970, dikutip di Suseno, 2003), yang dapat terwujud apabila pihak - pihak yang berkonflik dapat melakukan pengendalian diri dan mengesampingkan kepentingan - kepentingan pribadi, sehingga dapat mencapai kesepakatan bersama tanpa menimbulkan konflik yang baru atau semakin meluasnya konflik (Suseno, 1983; Suseno, 2003).

Adanya pengaruh kepentingan, secara ekonomi maupun politik, menandakan bahwa pihak pengurus dari kedua perguruan belum dapat mengesampingkan kepentingan masing - masing. Hal tersebut berdampak pada munculnya sikap mendukung dari sebagian pengurus perguruan dan sikap menolak dari pengurus lainnya terhadap hasil dari proses manajemen konflik. Adanya sikap mendukung dan menolak hasil dari proses manajemen konflik berakibat pada tidak maksimalnya proses sosialisasi hasil kepada anggota perguruan di tingkat grassroots, sehingga pengelolaan konflik di tingkat grassroots belum mencapai perubahan yang baik. Selain itu, adanya pengaruh kepentingan tersebut juga berdampak pada munculnya konflik baru dalam perguruan, misalnya terjadinya konflik internal dalam kepengurusan perguruan. Selanjutnya, mengacu pada Cooley (1992, dikutip di Hawkins, 1996) dan Jay (1969, dikutip di Hawkins, 1996), prinsip rukun juga mengacu pada aspek egalitarian, yaitu pandangan yang menyatakan bahwa semua individu yang menjadi anggota masyarakat memiliki kesamaan derajat (Aisyah BM, 2014; Cooley, 1992, dikutip di Hawkins, 1996; Jay, 1969, dikutip di Hawkins, 1996; Nurhidayati, 2010; Sudaryanto, 2008; Suparlan, 2001). Aspek egalitarian dalam proses manajemen konflik mengarah pada praktik demokrasi yang menekankan pada adanya kolektifitas dalam pengambilan keputusan atau pembuatan kebijakan (Beetham, dikutip di Held, 1993). Tercapainya kesepakatan Ikrar Damai dan terbentuknya Paguyuban Madiun Kampung Pesilat, pada dasarnya belum dapat mewakili semua suara dari anggota perguruan di tingkat grassroots. Tidak ada dialog berkelanjutan dari tingkat pengurus perguruan kepada anggota perguruan di tingkat grassroots. Hal tersebut kemudian memunculkan persepsi negatif dari anggota perguruan, yaitu kesepakatan tersebut dianggap hanya digunakan untuk menunjang kepentingan pribadi dari tingkat pengurus kedua perguruan. bahkan ada beberapa anggota perguruan yang tidak memahami maksud dan tujuan dari adanya kesepakatan - kesepakatan tersebut.

Selanjutnya, kaidah kedua dalam etika Jawa yaitu prinsip hormat. Prinsip hormat berorientasi pada adanya jenjang kasepuhan dan jenjang kanoman. Jenjang kasepuhan terdiri dari pengurus perguruan, sesepuh perguruan, dan tokoh masyarakat formal maupun informal, dan pada jenjang kanoman adalah anggota perguruan. Proses manajemen konflik yang telah dilakukan oleh pengurus dari kedua perguruan belum memperhatikan hubungan hierarkis tersebut. Interaksi yang dibangun dalam proses manajemen konflik masih pada lingkup antara pengurus dan tokoh masyarakat formal (pemerintah dan TNI/ POLRI), belum secara maksimal memberdayakan peran dari tokoh masyarakat informal. Anggota perguruan di tingkat grassroots cenderung memiliki seseorang yang ditokohkan atau dituakan di dalam lingkungan sosialnya. Seseorang yang dituakan atau ditokohkan tersebut diantaranya tokoh pemuda, tokoh agama, dan sesepuh perguruan. Tokoh - tokoh tersebut dapat dikatakan sebagai tokoh kunci dari anggota perguruan di tingkat grassroots. Sikap hormat anggota perguruan kepada tokoh - tokoh tersebut seringkali terwujud dalam tindakan sendiko dawuh atau patuh dengan nasehat dan perintah yang diberikan. Didasarkan pada bentuk interaksi yang terbangun antara anggota perguruan dengan tokoh masyarakat informal, maka sangat penting untuk melibatkan 
tokoh masyarakat informal dalam proses manajemen konflik, sehingga pendekatan dan pengendalian konflik lebih mudah dilakukan.

Kedua, aspek yang belum terpenuhi dalam proses manajemen konflik berkaitan dengan nilai hamemayu hayuning bawono, merupakan perilaku yang berorientasi pada keselamatan dunia, kesejahteraan, dan kebahagiaan sebagai tujuan utama. Hal yang mendasar dari nilai hamemayu hayuning bawono adalah hamemayu hayuning diri yang tercermin dari sikap waspodo, eling, dan berbudi luhur. Sikap waspodo merupakan sikap teliti dan selektif untuk mencapai keselamatan hidup (Endraswara, 2012). Belum terpenuhinya sikap waspodo terlihat pada proses pembuatan kebijakan atau keputusan yang hanya mengutamakan aspek hukum saja, belum memperhatikan aspek sosial budaya yang menjadi bagian dari kehidupan anggota perguruan, sehingga berdampak pada kondisi damai yang hanya bersifat kondisional saja atau jangka pendek. Sikap eling berorientasi pada kesadaran manusia terhadap adanya tata nilai dan norma masyarakat; dan sikap berbudi luhur yang berorientasi pada kemampuan manusia untuk membangun hubungan baik dengan manusia lainnya dan mengutamakan kepentingan bersama (Endraswara, 2012; Herdiyanto \& Yuniarti, 2012; Wagiran, 2012). Belum terpenuhinya sikap eling dan berbudi luhur terlihat pada adanya kepentingan lain yang muncul dalam proses manajemen konflik, utamanya kepentingan politik. Hal tersebut bertentangan dengan aturan yang tertera dalam Anggaran Dasar dari perguruan Persaudaraan Setia Hati Terate dan Persaudaraan Setia Hati Winongo Tunas Muda bahwa perguruan tersebut tidak terikat pada suatu golongan dan aliran tertentu serta tidak berafiliasi dengan partai politik. Adanya kepentingan lain tersebut juga menunjukkan bahwa selama proses manajemen konflik belum menunjukkan kenetralan dari kepentingan pribadi.

Ketiga, aspek yang belum terpenuhi dalam proses manajemen konflik berkaitan dengan nilai mangan ora mangan anggere kumpul, sebagai lambang kebersamaan (Kurniawati, Amatullah, \& Yuwono, 2013; Nugroho, 2011). Fokus utama dalam pembahasan nilai ini adalah pada sisi angota kedua perguruan yang seharusnya juga mendorong terwujudnya perdamaian kedua perguruan. Nilai mangan ora mangan anggere kumpul berorientasi pada ikatan atau solidaritas yang kuat antara anggota dalam satu perguruan. Kuatnya solidaritas antara anggota dalam satu perguruan ini sebenarnya dapat menjadi modal dasar untuk menjalin hubungan yang baik juga dengan anggota perguruan lain, melalui bentuk - bentuk kegiatan yang melibatkan kebersamaan dari anggota kedua perguruan. Namun, yang selama ini terjadi, solidaritas tersebut mengarah pada sikap fanatik yang berlebihan dan aksi - aksi balas dendam antar perguruan.

Berdasarkan pada penjelasan di atas, berikut model manajemen konflik yang didasarkan pada nilai kearifan lokal masyarakat Madiun dalam konflik antara perguruan pencak silat Persaudaraan Setia Hati Terate dan Persaudaraan Setia Hati Winongo Tunas Muda:

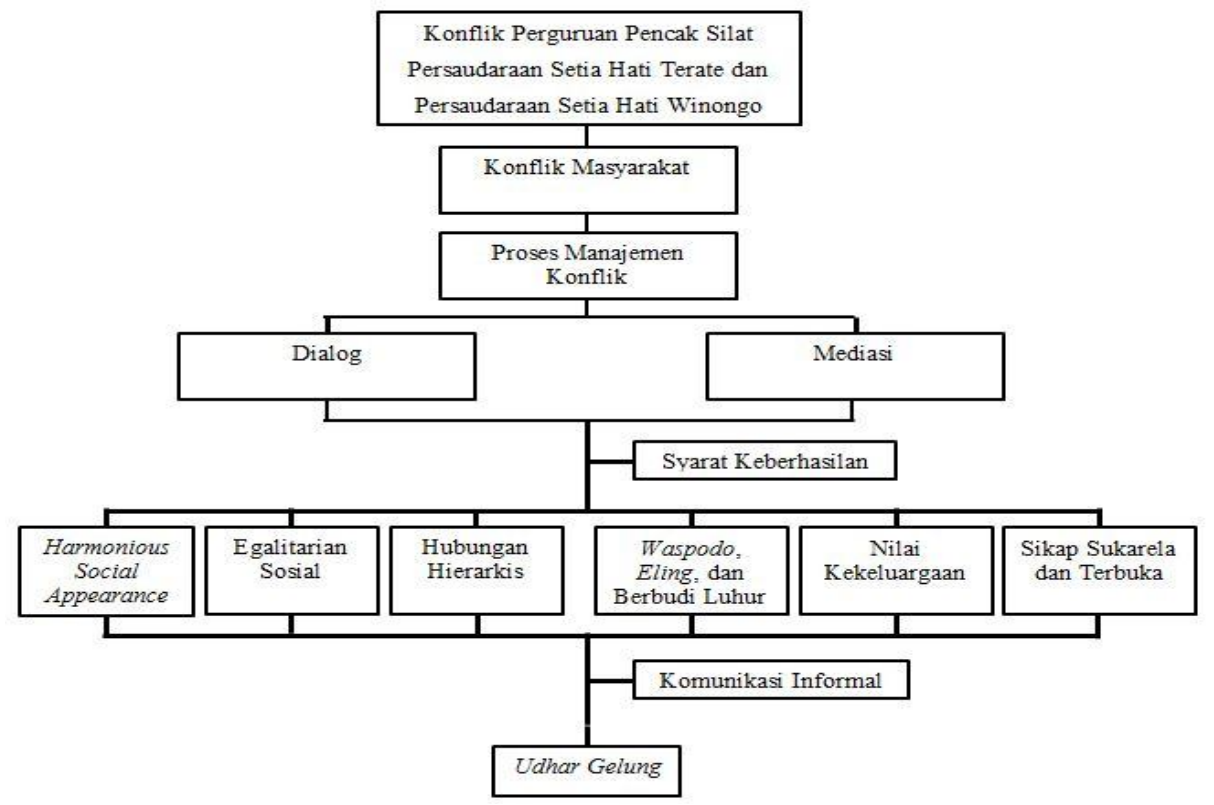

Gambar 1. Model Manajemen Konflik Masyarakat berdasarkan Kearifan Lokal Jawa Mataraman 
Mengacu pada model manajemen konflik tersebut, pada dasarnya pengurus perguruan dapat memanfaatkan bentuk komunikasi yang sudah berjalan di masyarakat Madiun, bernama udhar gelung, sebagai salah satu alternatif untuk melakukan pendekatan pada anggota perguruan di tingkat grassroots. Udhar gelung merupakan suatu bentuk komunikasi masyarakat Madiun yang bertujuan untuk mengekspresikan kehendak masyarakat, atau secara harafiah diartikan sebagai penguraian masalah.

Pada awalnya, udhar gelung diselenggarakan satu kali dalam satu tahun oleh pemerintah desa dan warga masyarakat.Permasalahan yang didiskusikan pun masih terbatas mengenai persoalan persoalan yang berkaitan dengan perekonomian masyarakat dan irigasi.Namun, saat ini, udhar gelung mengalami perubahan, mulai dari waktu pelaksanaan hingga permasalahan yang didiskusikan juga mencakup pada persoalan - persoalan sosial dan politik.

Udhar gelung dapat menjadi salah satu alternatif program untuk mengefektifkan proses manajemen konflik yang dilakukan oleh pengurus perguruan pencak silat Persaudaraan Setia Hati Terate dan Persaudaraan Setia Hati Winongo. Berdasarkan pada hasil analisis data penelitian, bentuk komunikasi yang tidak terus - menerus terjadi secara formal dan kedekatan antara pengurus dan anggota di tingkat bawah, menjadi hal yang utama yang harus diperhatikan dalam proses manajemen konflik, oleh karena itu, udhar gelung dapat menjadi salah satu media yang dapat menciptakan kedua kondisi tersebut. Namun, saat ini, pada sebagian besar wilayah di Madiun, udhar gelung sudah sangat jarang diselenggarakan, kalaupun masih diselenggarakan, sifatnya hanya situasional saja.

Berkaitan dengan proses manajemen konflik, udhar gelung diselenggarakan secara intensif satu kali dalam seminggu atau satu kali dalam sebulan oleh pengurus perguruan, sesepuh perguruan, tokoh masyarakat informal, dan anggota perguruan. Penyelenggaraan udhar gelung seringkali dikemas melalui bentuk - bentuk kegiatan yang bermacam - macam, diantaranya cangkrukan, sarasehan, arisan, dan pengajian.Udhar gelung dapat dikatakan sebagai salah satu alternatif yang efektif dalam mengelola konflik antara perguruan pencak silat Persaudaraan Setia Hati Terate dan Persaudaraan Setia Hati Winongo Tunas Muda dikarenakan, udhar gelung sangat memungkinkan anggota tingkat bawah untuk berani mengutarakan pendapat. Hal tersebut dilatarbelakangi oleh situasi yang tidak terlalu formal dan adanya figur yang dekat dengan anggota, bisa dari sesepuh perguruan atau dari tokoh masyarakat informal. Selain itu, melalui udhar gelung, anggota perguruan yang berada di tingkat bawah dapat selalu terlibat secara aktif dalam proses pembahasan rencana kegiatan yang bertujuan untuk menciptakan hubungan yang lebih baik antara anggota perguruan yang terlibat konflik.

\section{Model Manajemen Konflik dalam Kajian Komunikasi Perspektif Asia}

Aspek budaya Jawa Mataraman dalam model manajemen konflik, dapat menjadi salah satu alternatif penelitian yang dapat dijadikan sebagai fokus dalam kajian komunikasi yang berbasis pada perspektif Asia. Merujuk pada empat asumsi dalam kajian komunikasi perspektif Asia (Chen \& Starosta, 2003; Miike, 2002), yaitu pertama, asumsi ontologi yang menjelaskan bahwa eksistensi manusia tercermin melalui kedudukan manusia sebagai makhluk yang saling tergantung (Ishii, 1998, dikutip di Miike, 2002). Anggota perguruan yang merupakan masyarakat Madiun dan juga sebagai bagian dari wilayah kebudayaan Jawa Mataraman, dalam pemetaan model manajemen konflik berkaitan erat dengan konsep kosmologi, khususnya mengenai hubungan manusia dengan sesamanya. Asumsi kedua yaitu asumsi epistemologi yang menjelaskan bahwa orang dan segala sesuatu menjadi bermakna hanya dalam hubungan satu sama lain (Miike, 2002; Dissanayake, 1983, dikutip di Miike, 2002). Melalui proses manajemen konflik, terbangun interaksi yang melibatkan pengurus perguruan, anggota perguruan, dan tokoh masyarakat. Hubungan antara pengurus perguruan, anggota perguruan, dan tokoh masyarakat menjadi bermakna karena interaksi yang mereka lakukan didasarkan pada adanya tujuan untuk menciptakan perdamaian antara perguruan Persaudaraan Setia Hati Terate dan Persaudaraan Setia Hati Winongo Tunas Muda.

Asumsi ketiga, menjelaskan bahwa aspek spiritual masyarakat menjadi prioritas mereka dalam menjalani kehidupan.Pemetaan model manajemen konflik dilakukan dengan berpedoman pada nilai budaya masyarakat Madiun, termasuk mengenai sistem religi masyarakat, yang sangat mengutamakan keselarasan sosial dalam kehidupan. Hal tersebut berpengaruh terhadap perencanaan bentuk - bentuk kegiatan yang diperlukan dalam mengelola konflik antara kedua perguruan, berupa kegiatan kegiatan yang bersifat kerohanian, dengan tujuan untuk membentuk keseimbangan dalam diri anggota 
perguruan, keseimbangan antara olah fisik dan olah batin. Asumsi keempat, berkaitan dengan pegutamaan gaya komunikasi yang intuitif, halus, sensitif, dan tidak langsung. Asumsi ini dalam model manajemen konflik tercermin pada adanya hubungan hierarkis, yang terdiri dari jenjang kasepuhan dan jenjang kanoman.Hubungan hierarkis tersebut menjadi kunci dari efektifitas manajemen konflik, secara khusus untuk mengelola konflik yang terjadi dalam keseharian anggota perguruan di tingkat grassroots.

Selanjutnya, mengacu pada Dissanayake (2003, dikutip di Wang, 2011) yang menjelaskan mengenai beberapa bidang kajian yang dapat dieksplorasi untuk mengembangkan kajian komunikasi perspektif Asia, model manajemen konflik dalam fenomena konflik antara perguruan Persaudaraan Setia Hati Terate dan Persaudaraan Setia Hati Winongo Tunas Muda tergolong dalam dua bidang kajian, pertama, perilaku komunikasi sehari - hari. Model manajemen konflik yang didasarkan pada nilai kearifan lokal masyarakat Madiun merupakan suatu konsep perilaku komunikasi yang memiliki kekhasan, karena mengedepankan aspek sosial dan spiritual dari pihak - pihak yang terlibat konflik. Setiap aspek yang terkandung dalam model manajemen konflik tersebut tidak hanya sekedar bertujuan untuk mewujudkan perdamaian antara dua perguruan yang berkonflik, namun secara lebih luas juga mencakup pada tujuan - tujuan untuk mencapai keselamatan hidup, kesejahteraan, dan kebahagiaan lahir dan batin.

Bidang kajian kedua yaitu membangun elitism sebagai karakter dari komunikasi Asia.Tokoh elit yang dimaksudkan dalam hal ini adalah orang - orang yang memiliki kekuasaan atau pengaruh yang kuat dalam suatu lingkungan masyarakat.Model manajemen konflik yang didasarkan pada nilai kearifan lokal masyarakat Madiun dapat memunculkan peluang untuk membangun elitism, secara umum dalam lingkungan masyarakat, dan secara khusus dalam lingkup anggota perguruan. Hal tersebut berkaitan dengan adanya hubungan hierarkis yang menjadi kunci dari efektifitas model manajemen konflik.

Terdapat beberapa penelitian terdahulu yang menunjukkan peran dari tokoh masyarakat informal dan bentuk komunikasi yang digunakan dalam proses manajemen konflik. Pertama, penelitian yang dilakukan Brauchler (2009) mengenai konflik keagamaan di Maluku. Strategi perdamaian dilakukan melalui sistem tradisional pela gandong (Bräuchler, 2009). Kedua, penelitian yang dilakukan Retnowati (2014), mengenai upaya integrasi pasca konflik sosial di Situbondo Jawa Timur dengan melibatkan peran dari kyai sebagai tokoh masyarakat informal untuk mewujudkan toleransi sosial (Retnowati, 2014).Ketiga, penelitian yang dilakukan oleh Laksana (2013) mengenai konflik yang terjadi antara Pemerintah Kabupaten Pati, PT. Semen Gresik, dan masyarakat Sedulur Sikep di Pegunungan Kendeng Kabupaten Pati. Proses manajemen konflik dilakukan melalui bentuk komunikasi tradisional, yaitu srawung dan wungu rebo pon (Laksana, 2013).

Penelitian terdahulu tersebut menjadi pendukung hasil penelitian ini, yang berupa model manajemen konflik berdasarkan nilai kearifan lokal. Efektifitas model manajemen konflik berdasarkan nilai kearifan lokal masyarakat Madiun sangat bergantung pada peran tokoh masyarakat informal, juga pada bentuk - bentuk komunikasi yang digunakan. Proses dialog dan mediasi pada dasarnya tidak harus dilakukan dalam bentuk komunikasi secara formal, tetapi juga dapat dilakukan secara tradisional, seperti udhar gelung. Selain itu, proses dialog dan mediasi dilakukan tidak hanya mengutamakan pada aspek hukum saja, tetapi juga harus memperhatikan aspek sosial budaya masyarakat. Hal tersebut berpengaruh terhadap hasil yang akan dicapai.

\section{KESIMPULAN}

Budaya Jawa, oleh anggota perguruan dimaknai sebagai pedoman hidup yang memiliki nilai nilai dan ajaran - ajaran yang adiluhung. Pemaknaan tersebut berpengaruh terhadap pandangan anggota perguruan mengenai konflik, yaitu sebagai suatu hal yang mengganggu keharmonisan atau keselarasan sosial. Peran nilai kearifan lokal dalam proses manajemen konflik antara kedua perguruan dinilai sebagai suatu strategi yang tepat untuk mewujudkan perdamaian jangka panjang antara kedua perguruan.Pemetaan model manajemen konflik didasarkan pada nilai Etika Jawa, nilai hamemayu hayuning bawono, dan nilai mangan ora mangan anggere kumpul.

Pemetaan model manajemen konflik yang didasarkan pada nilai kearifan lokal masyarakat Madiun mengandung dua aspek utama, yaitu pertama, aspek sosial berupa mewujudkan perdamaian antara dua perguruan.kedua, aspek spiritual yang berorientasi pada pencapaian keselamatan hidup, 
kesejahteraan, dan kebahagiaan lahir maupun batin. Model manajemen konflik berdasarkan pada nilai kearifan lokal masyarakat Madiun sebagai bagaian dari wilayah kebudayaan Jawa Mataraman menempatkan tokoh masyarakat informal sebagai tokoh kunci dalam mewujudkan efektifitas proses manajemen konflik, karena dilatarbelakangi oleh adanya peran atau pengaruh yang kuat di masyarakat. Penelitian mengenai pemetaan model manajemen konflik berdasarkan nilai kearifan lokal dalam fenomena konflik antara peguruan pencak silat Persaudaraan Setia Hati Terate dan Persaudaraan Setia Hati Winongo Tunas Muda merupakan penelitian awal. Berdasarkan pada wilayah kebudayaan, penelitian ini masih sebatas dilakukan di wilayah Madiun dengan karakteristik budaya Jawa yang masih kuat, sehingga diperlukan penelitian - penelitian terkait dengan konflik masyarakat di wilayah lain, sehingga dapat memperkuat kekhasan dari proses manajemen konflik berdasarkan nilai kearifan lokal masyarakat Jawa Mataraman.

\section{DAFTAR PUSTAKA}

Aisyah BM, S. (2014). Konflik Sosial Dalam Hubungan Antar Umat Beragama. Dakwah Tabligh, 15(2), 189-208.

Astri, H. (2011). Penyelesaian konflik sosial melalui penguatan kearifan lokal. Aspirasi, 2 (2), 151 162.

Azra, A. (1999). Menuju masyarakat madani. Bandung: PT. Remaja Rosdakarya.

Bräuchler, B. (2009). Cultural Solutions to Religious Confl icts? Th e Revival of Tradition in the Moluccas , Eastern Indonesia, 37, 872-891.

Chen, G., \& Starosta, W. J. (2003). Asian Approaches To Human Communication, 12, 1-16.

Collier, P., Elliot, V. L., Hegre, H., Hoeffler, A., Querol, M. R., \& Sambanis, N. (2003). Breaking the conflict trap: civil war and development policy. Oxford: Oxford University Press.

Data konflik sosial. (2015). Diakses pada 17 April 2017, dari http://kesbangpol.kemendagri.go.id/index.php/subblog/pages/2015/350/Data-Konflik-Sosial

Dissanayake, W. (2003). Asian approaches to human communication: retrospect and prospect. Intercultural Communication Studies, XII (4), 17-38.

Endraswara, S. (2012). Aspek Budi Luhur dan Memayu Hayuning Bawana dalam Sastra Mistik Penghayat Kepercayaan Kaitannya dengan Pendidikan Karakter. Jurnal Pendidikan Karakter, 2(6), 225-238.

Fahmi, T., \& Akbar, M. Z. (2015). Pemetaan daerah rawan konflik sosial di Kabupaten Tanggamus. Jurnal Sosiologi, 17 (2), 111 - 121.

Firmansyah, A. L. I. (2016). Pandangan masyarakat terhadap konflik antar oknum perguruan silat.

Gustiana, S. (2013). Kajian Kriminologi terhadap Faktor Penyebab Terjadinya Konflik antar Anggota Perguruan Pencak Silat (Studi di Persaudaraan Setia Hati Tunas Muda Winongo dan Persaudaraan Setia Hati Terate serta Kepolisian Resort Kota Madiun). (Skripsi, Universitas Brawijaya, 2013). Diakses dari http://hukum.studentjournal.ub.ac.id/index.php/hukum/article/view/225/0

Haar, B. F., \& Krahé, B. (1999). Strategies for resolving interpersonal conflicts in adolescence: A German-Indonesian comparison. Journal of Cross-Cultural Psychology, 30(6), 667-683.

Hawkins, M. (1996). Is rukun dead? Ethonographic interpretations of social change and Javanese culture. The Australian Journal of Anthropology, 7(3), 218-234.

Held, D. (1993). Prospects for democracy north, south, east, west. Cambridge: Polity Press.

Herdiyanto, Y. K., \& Yuniarti, K. W. (2012). Budaya dan perdamaian: harmoni dalam kearifan lokal masyarakat Jawa menghadapi perubahan pasca gempa. Humanitas, IX (1), $28-42$.

Hindaryati, N. (2016). Model proses pewarisan nilai - nilai budaya lokal dalam tradisi masyarakat Buton. Sosiohumaniora, 18 (2), 108 - 115.

Irawanto, D. W., Ramsey, P. L., \& Ryan, J. C. (2011). Tailoring leadership theory to indonesian culture. Global Business Review, 12(3), 355-366.

Koentjaraningrat. (1993). Manusia dan kebudayaan di Indonesia. Jakarta: Djambatan.

Kriyantono, R. (2007). Teknik praktis riset komunikasi: disertai contoh riset media, public relations, komunikasi pemasaran dan organisasi. Jakarta: Kencana Prenada Media.

Kurniawati, N., Murti, W. M. A., Amatullah, M. F., \& Yuwono, S. (2013). Perilaku membahagiakan orang lain pada masyarakat Jawa. Paper dipresentasikan di Prosiding Seminar Nasional Parenting. Fakultas Psikologi Universitas Muhamadiya Surakarta: Center for Islamic and Indigeneous Psychology (CIIP). 
Kusumasari, B., \& Alam, Q. (2012). Local wisdom-based disaster recovery model in Indonesia. Disaster Prevention and Management: An International Journal, 21(3), 351-369.

Leung, K., \& Tjosvold, D. (1999). Conflict management in the Asia Pacific: assumptions and approaches in diverse culture. Singapore: John Wiley.

Listiana, A. (2014). Dinamika konflik perguruan silat Setia Hati (studi konflik Simon Fisher pada kasus konflik perguruan silat Setia Hati Terate dengan perguruan silat Setia Hati Tunas Muda Winongo di Madiun). Social Humanism, 3 (1), 1 - 22.

Littlejohn, S. W., \& Domenici, K. (2001). Engaging communication in conflict: systemic practice. Thousand Oaks, CA: Sage Publication, Inc.

Maksum, A. (2009). Konflik Kekerasan Antar Kelompok Perguruan Pencak Silat: Proses Pembentukan Identitas Sosial yang Terdistorsi, (January 2009).

Miike, Y. (2002). Theorizing Culture and Communication in the Asian Context: An Assumptive Foundation. Intercultural Communication Studies, 11(1), 1-22.

Mufid, A. S. (2010). Revitalisasi kearifan lokal dalam pemberdayaan masyarakat. Harmoni, 9 (34), 83 -92 .

Mulder, N. (1983). Abangan Javanese religious thought and practice. Journal of the Humanities and Social Sciences of Southeast Asia, 139 (2/ 3), 260 - 267.

Neuman, W. L. (2013). Metodologi penelitian sosial: pendekatan kualitatif dan kuantitatif (Ed. 7). Jakarta: PT. Indeks.

Neumeyer, H. (2006). Unity in diversity or diversity in unity: Indonesia's process of political decentralisation and its effects on conflicts. Law and Politics in Africa, Asia, and Latin America, 39 (3), 292 - 305.

Nugroho, A. (2011). Analisis Paribasan mengenai Kerukunan dalam Kajian Semantik. (Skripsi, Universitas Indonesia, 2011). Diakses dari http://lib.ui.ac.id/file?file=digital/20282824-S753Analisis\%20paribasan.pdf

Nurhidayati, T. (2010). Proses penyebaran nilai - nilai islam dalam tradisi masyarakat Jawa. Jurnal Falasifa, 1 (2), $73-92$.

Oetzel, J. G., \& Ting - Toomey, S. (2006). The SAGE handbook of conflict communication: integrating theory, research, and practice. Thousand Oaks, CA: Sage.

Panday, P. K., \& Jamil, I. (2009). Conflict in the Chittagong Hill Tracts of Bangladesh: an unimplemented accord and continued violence. Asian Survey, 49 (6), 1052 - 1070.

Pearce, W. B., \& Littlejohn, S. W. (1997). Moral conflict: when social worlds collide. Thousand Oaks, California: SAGE Publication, Inc.

Putnam, L. L. (2006). Definitions and approaches to conflict and communication. Dalam Oetzel, J. G., \& Ting - Toomey, S. The SAGE handbook of conflict communication: integrating theory, research, and practice. (h. 1).Thousand Oaks, CA: Sage.

Rasjidi, L., \& Wyasa, I. B. (1993). Hukum sebagai suatu sistem. Bandung: Remaja Rosdakarya.

Retnowati. (2014). Agama, konflik, dan integrasi sosial (integrasi sosial pasca konflik Situbondo). Analisa, 21 (02), 189 - 200.

Sasmito, P. (2016). Rapat Koordinasi Tim Terpadu Penanganan Konflik Sosial Bersama Pemerintah Kota Madiun. Diakses pada 17 April 2017, dari http://www.korem081madiun.com/index.php/kodim-0803-madiun/2503-rapat-koordinasi-timterpadu-penanganan-konflik-sosial-bersama-pemerintah-kota-madiun

Schefold, R. (1998). The domestication of culture; Nation-building and ethnic diversity in Indonesia. Bijdragen Tot de Taal-, Land- En Volkenkunde / Journal of the Humanities and Social Sciences of Southeast Asia, 154, 259-280.

Sudaryanto, A. (2008). Pola pewarisan di kalangan nelayan desa Pandanganwetan, kecamatan Kragan, kabupaten Rembang. Mimbar Hukum, 21 (1), 171 - 186.

Sugiyono. (2007). Metode penelitian kuantitatif kualitatif dan R\&D. Bandung: Alfabeta.

Suharno, \& Samsuri. (2013). Pengembangan Model Resolusi Konflik Untuk Masyarakat Multikultural (Studi Implementasi Kebijakan Resolusi Konflik di Sampit, Poso, dan Ambon), 1, 1-27.

Sulaeman, M. M. (2010). Dasar-Dasar Konflik dan Model Resolusi Konflik pada Masyarakat Desa Pantura Jabar. Sosiohumaniora, 12 (2), 175-190.

Suparlan, P. (2001). Kesetaraan Warga dan Hak Budaya Komuniti dalam Masyarakat Majemuk Indonesia 1. Antropologi Indonesia, 66, 18-21. 
Suparlan, P. (2006). Konflik Sosial dan Alternatif Pemecahannya. Jurnal Antropologi Indonesia, 30(2), 138-150.

Suprapto. (2013). Revitalisasi nilai - nilai kearifan lokal bagi upaya resolusi konflik. Walisongo, 21 (1), $19-38$.

Suseno, F. M. (1983). Etika sebagai kebijaksanaan hidup: catatan tentang struktur etika Jawa. Dalam Suseno, F. M., \& Reksosusilo, S. Etika Jawa dalam tantangan: sebuah bunga rampai. (h. 83). Yogyakarta: Kanisius.

Suseno, F. M. (2003). Etika Jawa: sebuah analisa falsafi tentag kebijaksanaan hidup Jawa. Jakarta: PT. Gramedia Pustaka Utama.

Sutarto, A., \& Sudikan, S. Y. (2004). Pendekatan kebudayaan dalam pembangunan Provinsi Jawa Timur. Jember: Kelompok Peduli Budaya dan Wisata Daerah Jawa Timur.

Syukur, F. A., \& Bagshaw, D. M. (2013). Court - annexed mediation in Indonesia: does culture matter?. Conflict Resolution Quarterly, 30 (3), 369 - 390. Doi: 10.1002/crq.21067.

Tjosvold, D., Chen, Y., \& Yu, Z. (2003). Conflict management for individual problem solving and term innovation in China. Journal of Working Paper, 2 - 44.

Laksana, L. U. A. (2013). Srawung: Strategi Advokasi Masyarakat Sedulur Sikep terhadap Rencana Pendirian Pabrik Semen. (Skripsi, Universitas Gajah Mada, 2013). Diakses dari http://etd.repository.ugm.ac.id/index.php?mod=penelitian detail\&sub=PenelitianDetail\&act=vi ew\&typ=html\&buku id=64968

Wagiran. (2012). Pengembangan Karakter Berbasis Kearifan Lokal Hamemayu Hayuning Bawana. Pendidikan Karakter, (2), 1-18.

Wahyono, S. B. (2003). Kejawen dan Aliran Islam (Studi tentang Respons Kultural dan Politik Masyarakat Kejawen terhadap Penetrasi Gerakan Islam Puritan di Yogyakarta). (Disertasi, Universitas Airlangga, 2003). Diakses dari http://repository.unair.ac.id/32555/

Walter, B. F. (2010). Conflict relapse and the sustainability of peace. California: World Bank.

Wang, G. (2011). De - westernizing communication research: altering question and changing frameworks. London: Routledge

Wilmot, W., \& Hocker, J. (2001). Interpersonal conflict (6th ed.). Dubuque, IA: William C. Brown.

Yulianie, D. (2015). Tradisi Konflik Perguruan Silat Setia Hati (Studi Kasus Perguruan Silat Setia Hati Terate dengan Setia Hati Tunas Muda Winongo di Kabupaten Madiun). (Skripsi, Universitas Sebelas Maret, 2015). Diakses dari https://digilib.uns.ac.id/dokumen/detail/49727/

Zuliansyah, M. A. (2017). Sowan kyai, komunikasi perspektif masyarakat Islam - Jawa. Jurnal Komunikator, 9 (2), 95 - 104. 